\title{
Tuning LSAF Perovskite Morphology by Synthesis Method
}

\section{Sentez Yöntemi ile LSAF Perovskit Morfolojisinin Ayarlanması}

Geliş / Received: 29/07/2021

\author{
Rahmiye Zerrin Yarbay Şahin ${ }^{1 *}$
}

Revize / Revised: 24/08/2021

Kabul / Accepted: 01/09/2021

\begin{abstract}
Lanthanum strontium aluminum ferrite $\left(\mathrm{La}_{0.8} \mathrm{Sr}_{0.2} \mathrm{Al}_{0.2} \mathrm{Fe}_{0.8} \mathrm{O}_{3 \pm \delta}\right.$ - LSAF) perovskites are drawing attention as cathodes in solid oxide fuel cells (SOFCs). The structural properties of these materials are mostly counting on the methods of preparation. In this study, two different preparation methods namely hydrothermal and sol-gel were applied to prepare LSAF perovskite. The characterization results including scanning electron microscopy (SEM), $\mathrm{N}_{2}$ adsorption-desorption, and Fourier transform infrared spectroscopy (FT-IR) are investigated in detail. The results showed that the preparation method played an important role on the microstructure of the LSAFs. It can be highlighted that the hydrothermal method is more successful in obtaining quite small nanoparticles.
\end{abstract}

Keywords- LSAF, Hydrothermal Method, Nanopowder, Sol-gel Method

\section{$\overline{\mathrm{OZZ}}$}

Lantan stronsiyum alüminyum ferrit $\left(\mathrm{La}_{0.8} \mathrm{Sr}_{0.2} \mathrm{Al}_{0.2} \mathrm{Fe}_{0.8} \mathrm{O}_{3 \pm \delta}\right.$-LSAF) perovskitleri, katı oksit yakıt hücrelerinde (KOYP) katot olarak dikkat çekmektedir. Bu malzemelerin yapısal özellikleri çoğunlukla hazırlama yöntemlerine dayanmaktadır. Bu çalı̧̧mada, LSAF perovskite hazırlamak için hidrotermal ve sol-jel olmak üzere iki farklı hazırlama yöntemi uygulanmıştır. Taramalı electron mikroskobu (SEM), $\mathrm{N}_{2}$ adsorpsiyon-desorpsiyon ve Fourier transform kızıl ötesi spektroskopisini (FT-IR) içeren karakterizasyon sonuçları detaylı olarak incelenmiştir. Sonuçlar, hazırlama yönteminin LSAF'lerin mikro yapısında önemli bir rol oynadığını göstermiştir. Oldukça küçük nano parçacıkların elde edilmesinde hidrotermal yöntemin daha başarılı olduğu görülmüştür.

Anahtar Kelimeler- LSAF, Hidrotermal Metot, Nanotoz, Sol-jel Metodu

1*Sorumlu yazar iletișim: zerrin.yarbay@bilecik.edu.tr(https://orcid.org/0000-0002-4926-044X) Kimya Mühendisliği Bölümü, Bilecik Şeyh Edebali Üniversitesi, Mühendislik Fakültesi, Bilecik, Türkiye Bilecik Şeyh Edebali Üniversitesi Enerji Teknolojileri Uygulama ve Araştırma Merkezi, Bilecik, Türkiye 


\begin{tabular}{|c|c|c|}
\hline & $\begin{array}{l}\text { BŞEÜ Fen Bilimleri Dergisi } \\
8(2), 893-900,2021\end{array}$ & $\begin{array}{r}\text { BSEU Journal of Science } \\
\text { https://doi.org/10.35193/bseufbd.975808 }\end{array}$ \\
\hline $\begin{array}{l}\text { CIKSSEYH EDEBALI } \\
\text { VERSITESI }\end{array}$ & & 2458-7575 (https://dergipark.org.tr/tr/pub/bseufbd) \\
\hline
\end{tabular}

\section{INTRODUCTION}

The solid oxide fuel cells (SOFC's) which are known as skilled and clean electric generators have been commonly investigated in the last decades. These devices generally work at high temperatures $\left(600-1000{ }^{\circ} \mathrm{C}\right)$, and their components should be chemically compatible to run long durations [1]. One of the main drawbacks is significantly declined performance of cathode components while operating at low temperatures.

Lanthanum strontium ferrite (LSF) is of interest as cathode candidate in SOFC [2,3]. On the other hand, this material is not adequately effective for practical applications at the low end of $650-900^{\circ} \mathrm{C}$ temperature range. Thus, recent studies which focus on improving LSF are still underway [3].

LSF materials is in the class of the perovskite type materials with $\mathrm{ABO}_{3}$ crystal structure which enables using a wide range of A-site and B-site elements which form stable compounds. Substitution of divalent ions for trivalent ions on the A-site is possible to be accommodated in the perovskite structure by a change in oxygen stoichiometry or valence of the B-site ion [4]. Thus, doping on the perovskite B site with elements is expected to ease redox activity [5]. In the literature, Lanthanum strontium aluminum ferrite (LSAF), where Al has been added as the second B element to LSF, was described to as another interesting candidate [2].

The structural properties of perovskites are mostly counting on the preparation method [6]. Perovskite synthesis can be widely done in several methods such as co-precipitation [7], sol-gel [7- 9] and spray pyrolysis method [10]. Sol-gel method is one of the most fundamental, practical and routine methods which has been used, developed and modified in studies for many years. The particles exist a gel structure in this method [11]. Sol-gel is very useful in obtaining perovskites with high phase purity [12]. Hydrothermal method is also a very popular and appropriate technique for the synthesis of numerous multi-component oxide materials [13]. The benefit of soft chemical ways like hydrothermal method was that microcrystallines could be synthesized at a much lower temperature, and also energy saving and cost effective.

To the best of our knowledge, a clear elucidation of the relationship between the structure and preparation method of LSAFs has not yet been reported. In order to meet this demand, two important methods (sol-gel and hydrothermal) are chosen to apply. The sol-gel method is applied as one of the fundamental methods in order to compare with one of the latest but famous for decreasing particle size known as the hydrothermal method. Therefore, in this study, LSAF materials were synthesized by hydrothermal and sol-gel methods in order to examine the preparation method influence on material morphology and characterized by scanning electron microscopy (SEM), $\mathrm{N}_{2}$ adsorption-desorption isotherms and Fourier transform infrared spectroscopy techniques. The characterization results are discussed in detail.

\section{MATERIALS AND METHODS}

\section{A. Synthesis Methods}

Hydrothermal method and sol-gel method were chosen to prepare the $\mathrm{La}_{0.8} \mathrm{Sr}_{0.2} \mathrm{Al}_{0.2} \mathrm{Fe}_{0.8} \mathrm{O}_{3 \pm \delta}$ perovskites. All the details of the synthesis methods are given in Figure 1 for hydrothermal method and Figure 2 for sol-gel method. A receipt adopted from Koch et al. [14] used for hydrothermal method. In the sol-gel method, the procedure given by Hussein et al. [15] was applied. While the hydrothermally prepared perovskite is denoted as HT, sol-gel prepared perovskite is labelled as SG. 


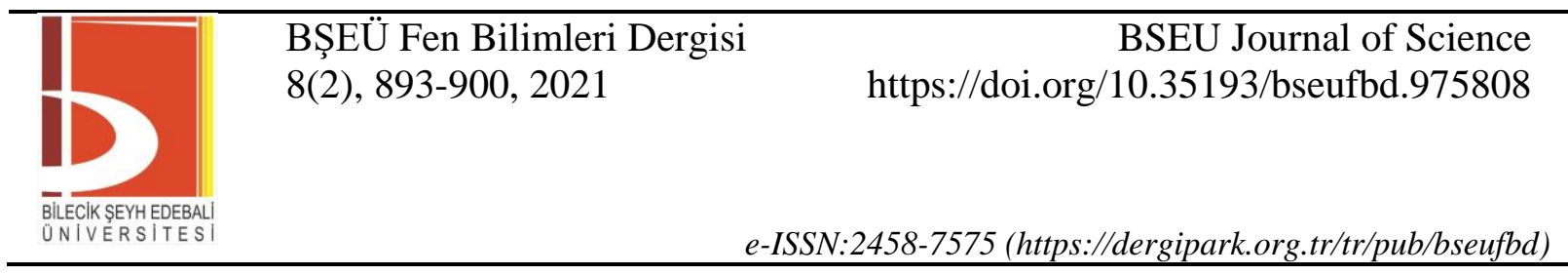

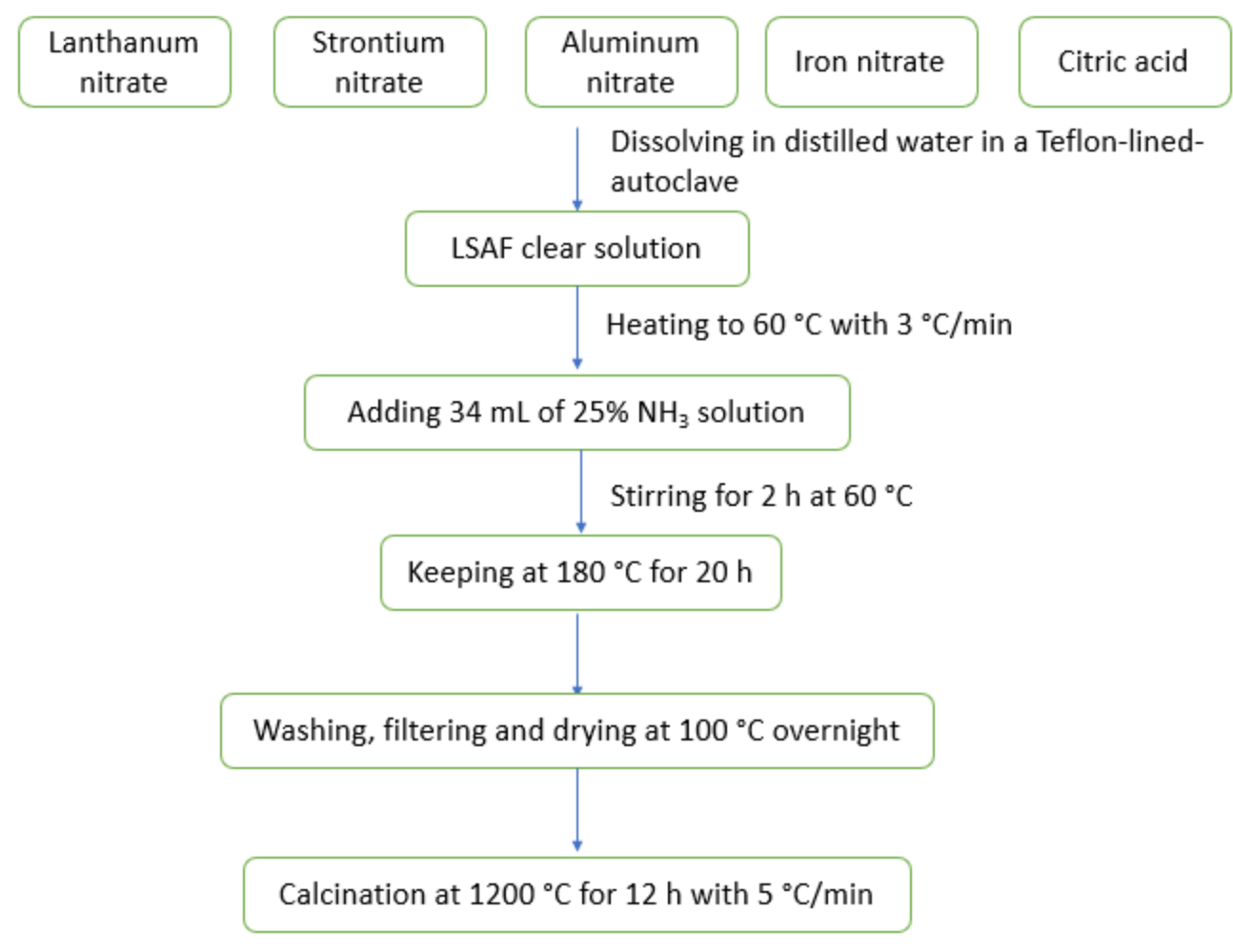

Figure 1. Flow chart of the synthesis of LSAF using hydrothermal method

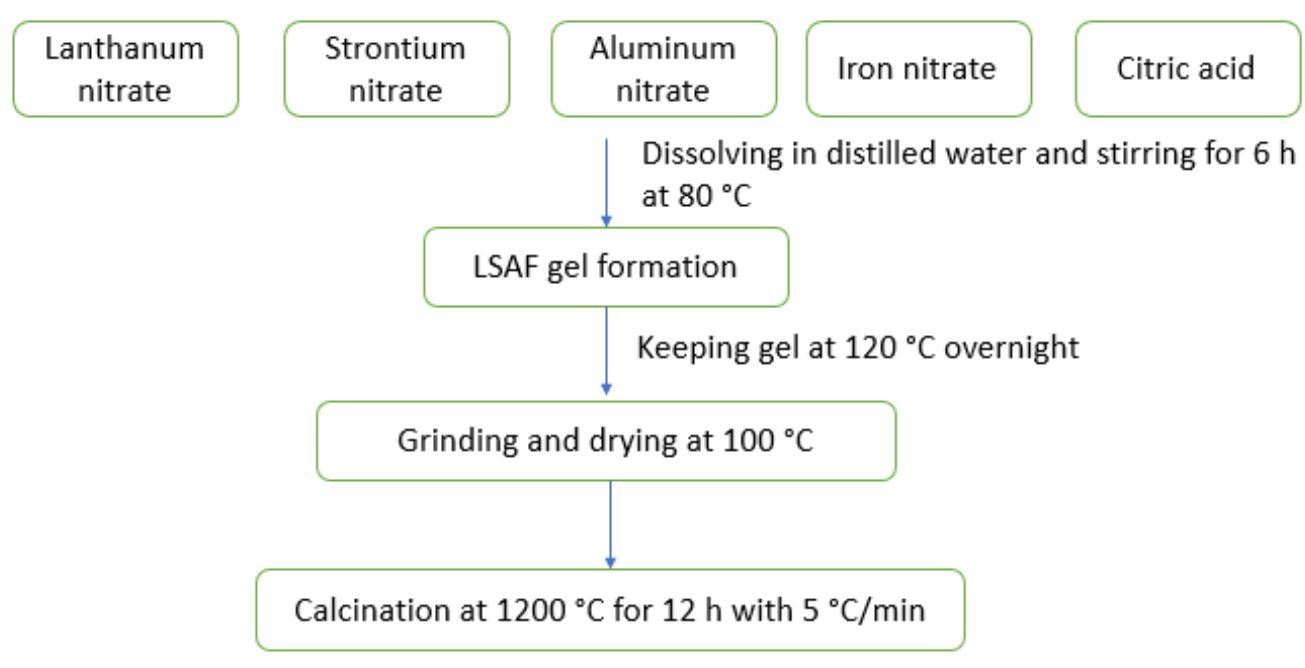

Figure 2. Flow chart of the synthesis of LSAF using sol-gel method

\section{B. Characterization}

The morphology of the LSAFs was monitored using a Zeiss Supra VP 40 scanning electron microscope (SEM) using SE2 detector while operating at $15 \mathrm{kV}$. The textural properties of the LSAFs were collected from nitrogen physisorption measurements at a relative pressure of $\mathrm{P} / \mathrm{Po}=0.98$ using a Micromeritics ASAP 2020 instrument. The Fourier transform infrared spectroscopy (FT-IR) spectrum of the samples were recorded using Agilent Cary 630 Spectrometer in powder form. 


\begin{tabular}{|c|c|c|}
\hline & $\begin{array}{l}\text { BŞEÜ Fen Bilimleri Dergisi } \\
8(2), 893-900,2021\end{array}$ & $\begin{array}{r}\text { BSEU Journal of Science } \\
\text { https://doi.org/10.35193/bseufbd.975808 }\end{array}$ \\
\hline $\begin{array}{l}\text { CIKSEYHED } \\
\text { VERS IT }\end{array}$ & & 2458-7575 (https://dergipark.org.tr/tr/pub/bseufbd) \\
\hline
\end{tabular}

\section{RESULTS AND DISCUSSION}

SEM images of LSAFs are given in Figure 3 and Figure 4. From the morphological point of view, the SEM nano-graph of LSAF prepared by hydrothermal method shown in Figure 3 indicated that the sample is homogeneous, nano-structured, and quite porous and particles are well contacted with each other. At lower magnifications in Figure 3 (a), (b), and (c), although the porous structure does not contain spherical particles, the higher magnification in Figure 3 (d) displays the spherical nano-sized particles. Indeed, LSAF samples prepared by sol-gel method exhibited the most regular grain shape and size with homogeneous pore distribution in Figure 4 (a), (b), and (c), a kind of agglomerations between particles were observed as shown in Figure 4 (d). The agglomerations are made of particles that are collapsed in microstructure compared to sample prepared by hydrothermal method. When x 5000 magnifications of both materials were compared, the LSAF prepared with the hydrothermal method formed smaller nanoparticles than the sol-gel method.

The essential characteristic of cathodes for SOFC is the porous structure, for example through the chemical reaction resulting advantage of shifting of electrons/ions and as well rises the length of triple phase boundary (TPB) [15]. Therefore, although both of the preparation methods resulted with materials with high porosities, the hydrothermal method was more successful.

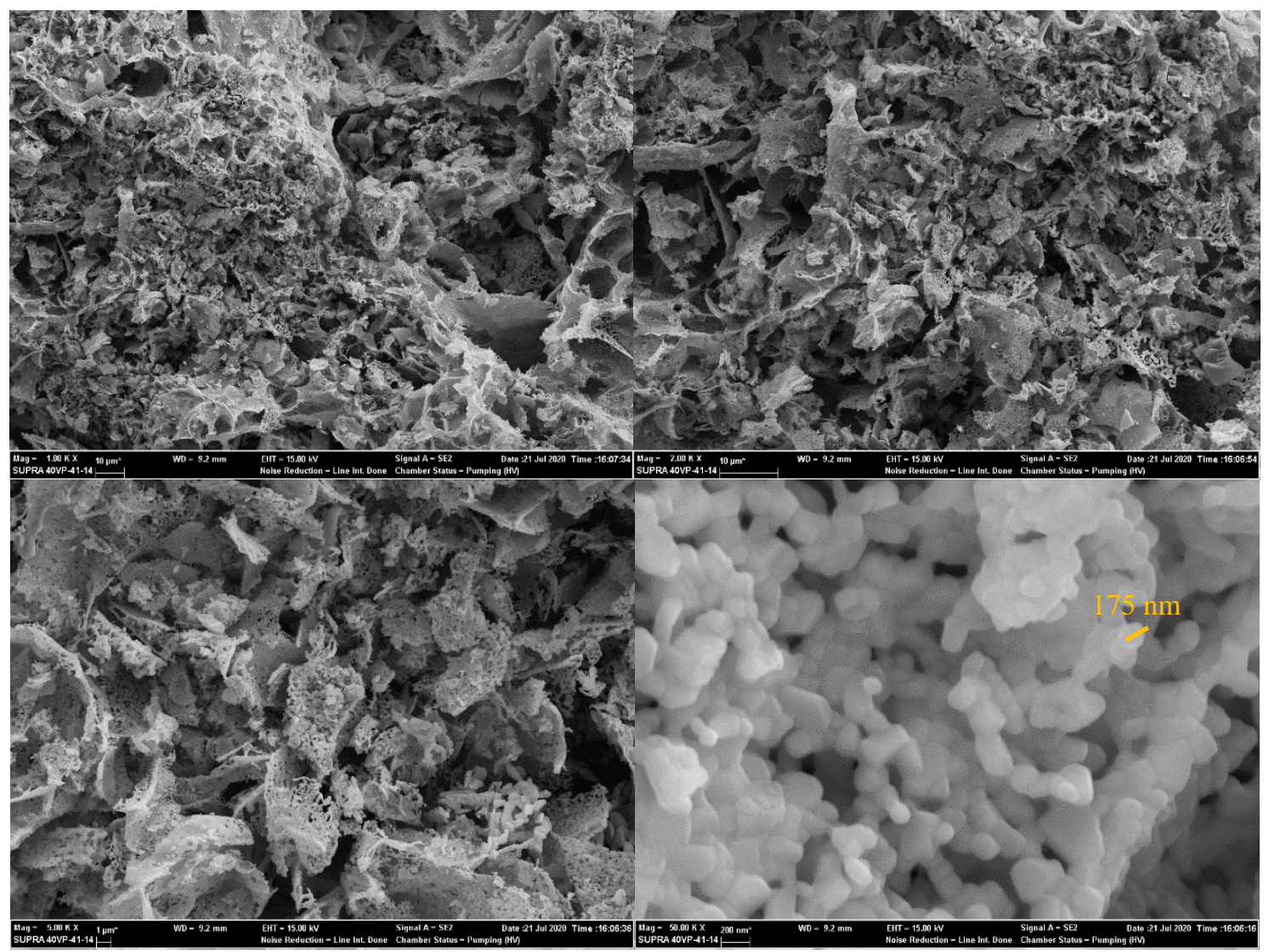

Figure 3. SEM images of LSAF samples prepared by hydrothermal method (a) 1000 zoom, (b) 2000 zoom, (c) 5000 zoom, (d) 50000 zoom. 


\begin{tabular}{|c|c|c|}
\hline & $\begin{array}{l}\text { BŞEÜ Fen Bilimleri Dergisi } \\
8(2), 893-900,2021\end{array}$ & $\begin{array}{r}\text { BSEU Journal of Science } \\
\text { https://doi.org/10.35193/bseufbd.975808 }\end{array}$ \\
\hline $\begin{array}{l}\text { BILECIK SEYH EDEBALI } \\
\text { ONIVERSITESI }\end{array}$ & & 2458-7575 (https://dergipark.org.tr/tr/pub/bseufbd) \\
\hline
\end{tabular}

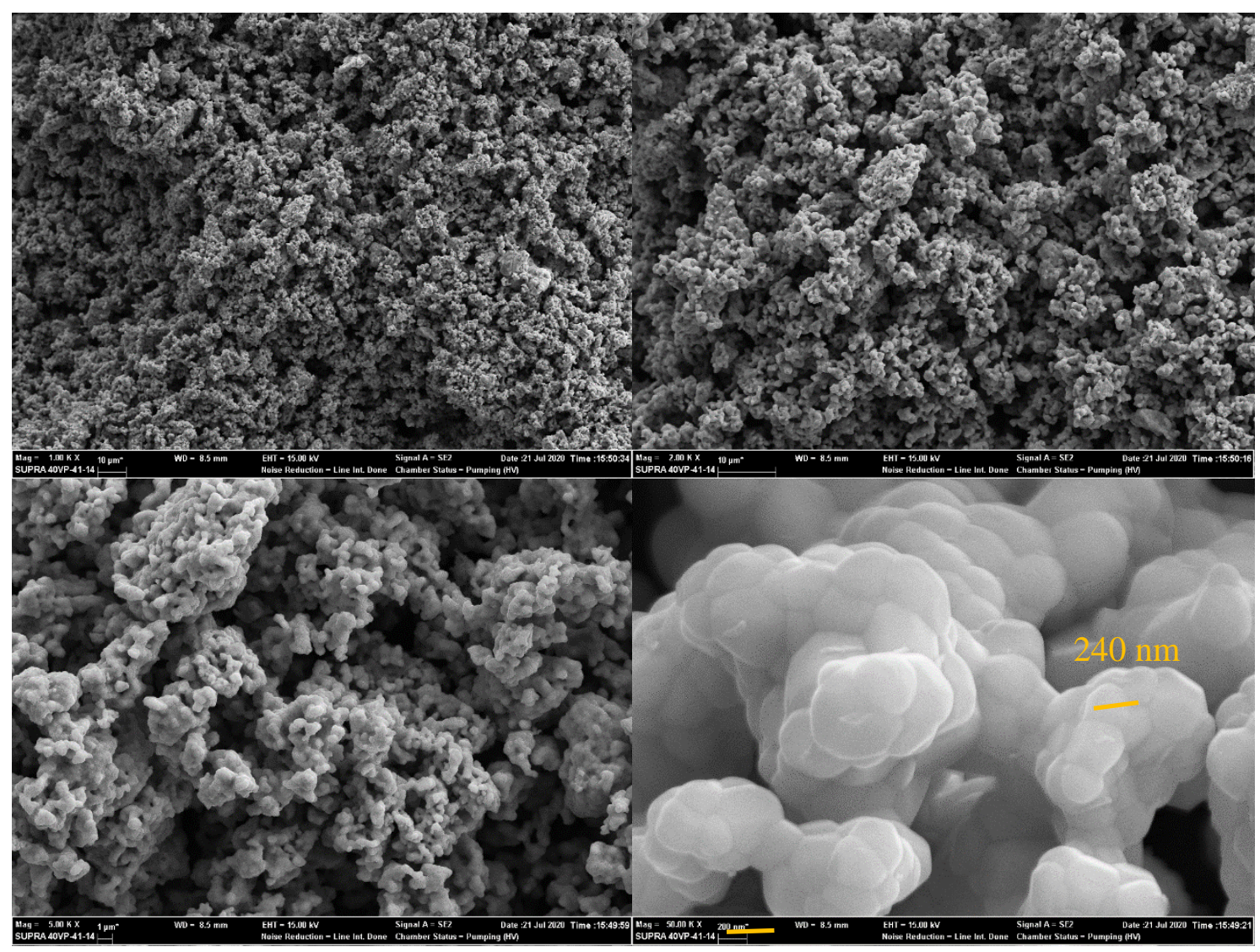

Figure 4. SEM images of LSAF samples prepared by sol-gel method (a) 1000 zoom, (b) 2000 zoom, (c) 5000 zoom, (d) 50000 zoom

The Brunauer-Emmett-Teller (BET) surface area values and the total pore volume are shown in Table 1. Hydrothermal method gave higher surface areas compared to the sol-gel method. The specific surface area value decreases from $2.59 \mathrm{~m}^{2} / \mathrm{g}$ for the hydrothermal method to $0.30 \mathrm{~m}^{2} / \mathrm{g}$ for the sol-gel method used. These lower BET surface areas of the perovskites fall in agreement with the literature data [7-9].

The average crystallite sizes of LSAF perovskites similarly displayed differences in terms of smaller particles obtained with hydrothermal method. These results suggest that preparation of LSAF by hydrothermal method did not result the particles collapsing during the calcination step. Therefore, it is approved that the hydrothermal technique can save energy and time due to the faster kinetics of crystallization.

Table 1. Textural properties of the LSAFs

\begin{tabular}{l|ccc}
\hline Material & BET surface area $\left(\mathbf{m}^{2} / \mathbf{g}\right)$ & Total pore volume $\left(\mathbf{c m}^{3} / \mathbf{g}\right)$ & Pore diameter $(\mathbf{n m})$ \\
\hline$L S A F_{-} H T$ & 2.59 & 0.005 & 7.84 \\
$L S A F_{-} S G$ & 0.30 & 0.001 & 30.4 \\
\hline
\end{tabular}

Figure 5 illustrates $\mathrm{N}_{2}$ isotherms of the LSAF perovskites. Both samples displayed similar isotherms and hysteresis loops. However, the $\mathrm{N}_{2}$ uptake of the sample prepared by hydrothermal method was significantly greater than the one prepared with sol-gel, which was characteristic of well-developed porosity. While $\mathrm{N}_{2}$-adsorbed volume rise at the relative pressure range between 0.5 and 1 is produced by the filling of mesopores by $\mathrm{N}_{2}$ in sample prepared with sol-gel, the isotherm of the LSAF prepared by hydrothermal method showed a steep increase in the range between 0.8 and 1 in $\mathrm{N}_{2}$ adsorption which is suggested the presence of small micropores. The isotherm types were classified by the IUPAC classification. Regarding the classification, type $\mathrm{V}$ isotherm was observed. Type $\mathrm{V}$ isotherm is a special case of adsorption in micro- and/or mesopores where the interactions between the adsorbent and the adsorptive are rather weak [16]. In this regard, this type of isotherm represents cases with no identifiable multilayer development [17]. 


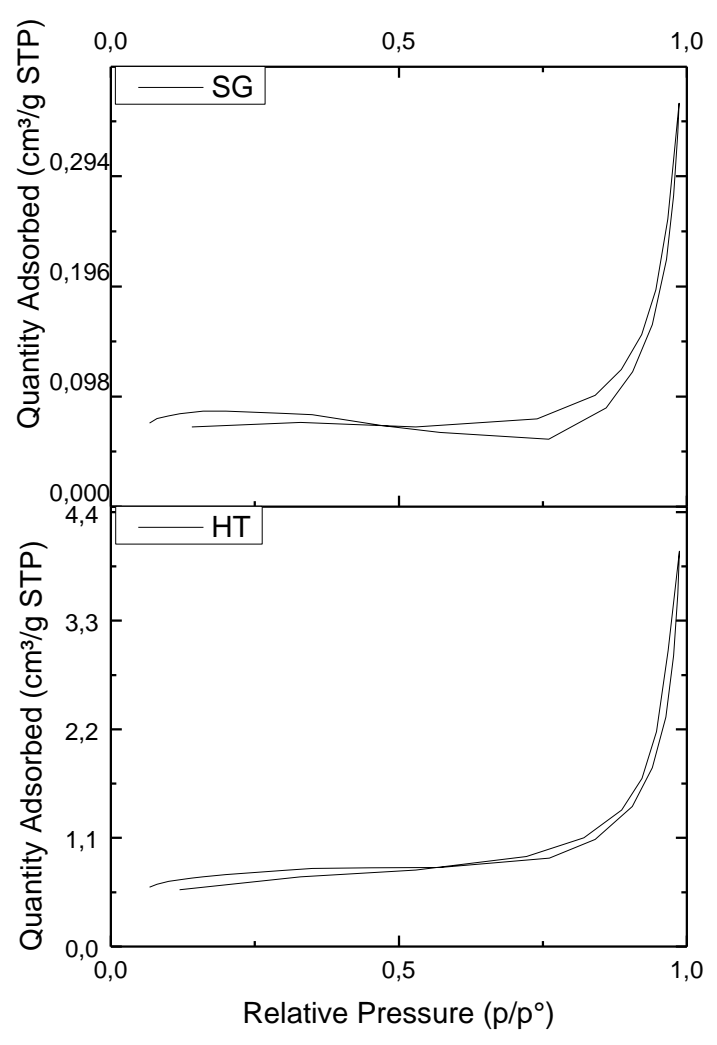

Figure 5. $\mathrm{N}_{2}$ adsorption/desorption isotherms of LSAFs

LSAF perovskites were also characterized by FT-IR spectroscopy and the results are given in Figure 6. Although both samples exhibited similar peaks, the sol-gel method used sample showed more peaks. For the common peaks of the samples, $\sim 1070 \mathrm{~cm}^{-1}$ could be attributed to the asymmetrical stretching vibration of C-O$\mathrm{C}$ groups. The peaks at 540 and $569 \mathrm{~cm}^{-1}$ appeared in both samples could be related to La-O vibrations. Also, this sharper peak is known to by reason of the existence of stretching vibration of $\mathrm{Fe}-\mathrm{O}$ approves the octahedral $\mathrm{FeO}_{6}$ existence in the structure. Therefore, it is better to underline here that in the literature, especially in case of the "700-400 $\mathrm{cm}^{-1}$ " region of the IR spectrum, it is well-known that peaks may be attributed to the characteristic Metal-Oxygen bond vibrations for the perovskite structure compounds [18]. 


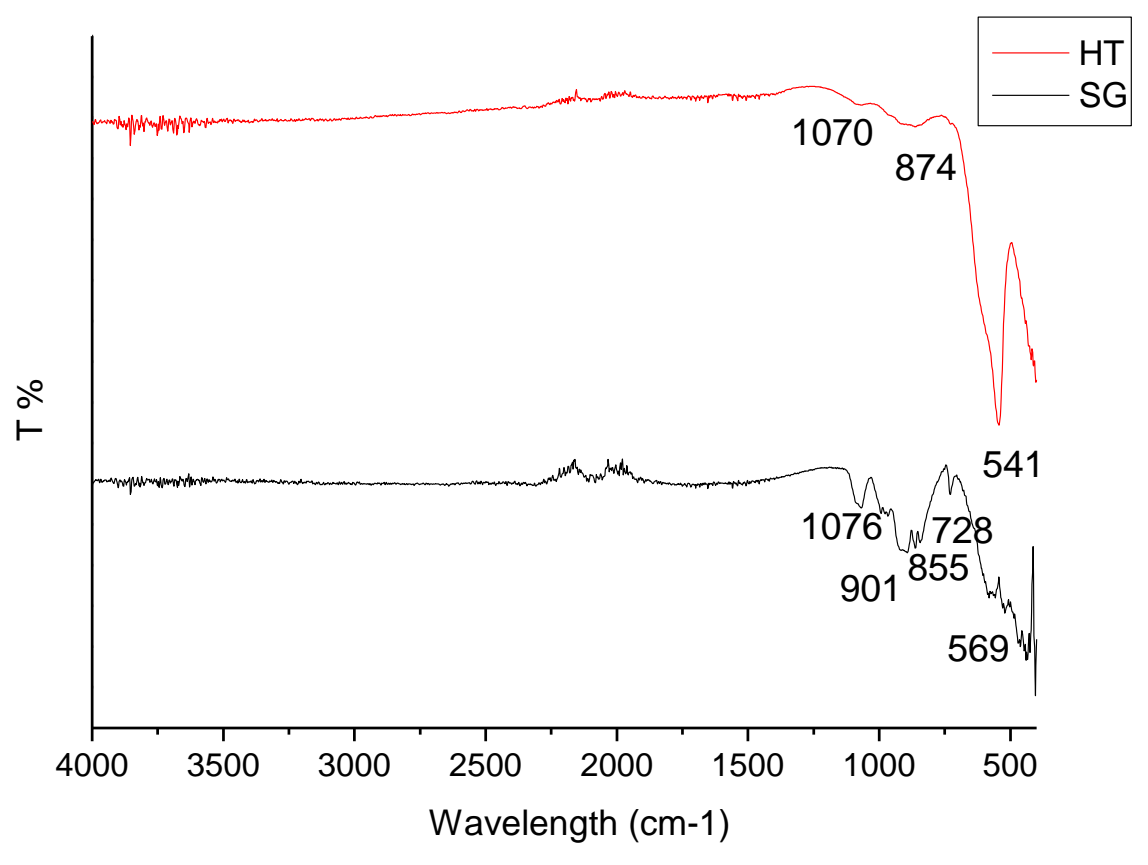

Figure 6. FT-IR spectra of LSAFs

\section{CONCLUSION}

In this study, LSAF perovskites were prepared using two preparation methods: the sol-gel, and hydrothermal method. Although the sol-gel method is a well-known representative preparation method for perovskite materials, the hydrothermal method has gained attention recently. Based on the results, when x 5000 magnifications of both materials were compared, the LSAF prepared with hydrothermal method formed smaller nanoparticles than the sol-gel method. Besides, the hydrothermal method gave a higher surface area compared to the sol-gel method. The characterization results showed that the materials were successfully prepared by both methods, and it is worth investigating the electrochemical behaviours of these materials for oxygen reduction to lay out their potential as cathode materials in SOFCs. We would like to stress that these findings will contribute to the systematic preparation design of porous LSAF perovskites.

\section{REFERENCES}

[1] Guimarães, A. O., Mansanares, A. M., Guimarães, V. F., PaesJr, H. R., \& Vargas, H. (2013). Assessment of the thermal expansion mismatch in lanthanum strontium cobalt ferrite-yttria stabilized zirconia two-layers systems using photoacoustic methodology. Applied Physics Letters, 102(13), 131910.

[2] Coffey, G. W., Hardy, J., Pedersen, L. R., Rieke, P. C., Thomsen, E. C., \& Walpole, M. (2003). Electrochemical properties of lanthanum strontium aluminum ferrites for the oxygen reduction reaction. Solid State Ionics, 158(1-2), 1-9.

[3] Coffey, G. W., Hardy, J. S., Pederson, L. R., Rieke, P. C., \& Thomsen, E. C. (2003). Oxygen reduction activity of lanthanum strontium nickel ferrite. Electrochemical and Solid State Letters, 6(6), A121.

[4] Striker, T., Ruud, J. A., Gao, Y., Heward, W. J., \& Steinbruchel, C. (2007). A-site deficiency, phase purity and crystal structure in lanthanum strontium ferrite powders. Solid State Ionics, 178(21-22), 1326-1336.

[5] Coffey, G., Hardy, J., Marina, O., Pederson, L., Rieke, P., \& Thomsen, E. (2004). Copper doped lanthanum strontium ferrite for reduced temperature solid oxide fuel cells. Solid State Ionics, 175(1-4), 73-78.

[6] Berchmans, L. J., Leena, V., Amalajyothi, K., Angappan, S., \& Visuvasam, A. (2009). Preparation of lanthanum ferrite substituted with Mg and Ca. Materials and Manufacturing Processes, 24(5), 546-549.

[7] Yarbay, R. Z., \& Baykara, S. Z. (2011). Partial Substitution of Lanthanum with Silver and Strontium in the $\mathrm{LaNiO}_{3}$ Perovskite: Effect of the Preparation Method. Energy Challenges for Advanced Materials and Processes (ECAMP 2011). 25-29 Mayis, Niğde. 
[8] Özbay, N., \& Şahin, R. Z. Y. (2020). Effect of preparation method and B-side metal type on the physicochemical properties of $\mathrm{LaBO}_{3}$ perovskite catalyst and its catalytic behaviour in the biomass pyrolysis. Biomass Conversion and Biorefinery, 1-14.

[9] Şahin, R. Z. Y., \& Özbay, N. (2021). Perspective on Catalytic Biomass Pyrolysis Bio-oils: Essential Role of Synergistic Effect of Metal Species Co-substitution in Perovskite Type Catalyst. Catalysis Letters, 151(5), 1406-1417.

[10] Kuai, L., Kan, E., Cao, W., Huttula, M., Ollikkala, S., Ahopelto, T., ... \& Geng, B. (2018). Mesoporous $\mathrm{LaMnO}_{3+\delta}$ perovskite from spray- pyrolysis with superior performance for oxygen reduction reaction and $\mathrm{Zn}$ - air battery. Nano Energy, 43, 81-90.

[11] Yarbay Şahin, R. Z. (2019). Effect of Calcination Temperature on the Perovskite Characteristics Prepared by Modified Pechini Method. Avrupa Bilim ve Teknoloji Dergisi, 17, 750-754.

[12] Yarbay, R. Z., Figen, H. E., \& Baykara, S. Z. (2012). Effects of cobalt and nickel substitution on physical properties of perovskite type oxides prepared by the sol-gel citrate method. Acta Physica Polonica-Series A General Physics, 121(1), 44.

[13] Ifrah, S., Kaddouri, A., Gelin, P., \& Leonard, D. (2007). Conventional hydrothermal process versus microwave-assisted hydrothermal synthesis of $\mathrm{La}_{1-\mathrm{x}} \mathrm{AgxMnO}_{3+\delta}(\mathrm{x}=0,0.2)$ perovskites used in methane combustion. Comptes Rendus Chimie, 10(12), 1216-1226.

[14] Koch, G., Hävecker, M., Teschner, D., Carey, S. J., Wang, Y., Kube, P., ... \& Trunschke, A. (2020). Surface Conditions That Constrain Alkane Oxidation on Perovskites. ACS Catalysis, 10(13), 7007-7020.

[15] Hussain, F., Ahmad, M. A., Raza, R., Khan, M. A., Rehman, Z. U., Riaz, R. A., \& Abbas, G. (2019). Electrochemical investigation of multi-fuel based low temperature nano-composite anode for solid oxide fuel cell. Journal of Power Sources, 425, 147-152.

[16] Özbay, N., \& Şahin, R. Y. (2017, February). Preparation and characterization of $\mathrm{LaMnO}_{3}$ and $\mathrm{LaNiO}_{3}$ perovskite type oxides by the hydrothermal synthesis method. AIP Conference Proceedings, 1809(1), 020040.

[17] Sotomayor, F. J., Cychosz, K. A., \& Thommes, M. (2018). Characterization of micro/mesoporous materials by physisorption: concepts and case studies. Acc. Mater. Surf. Res, 3(2), 34-50.

[18] Djoudi, L., Omari, M., \& Madoui, N. (2012). Synthesis and characterization of lanthanum monoaluminate by co-precipitation method. EPJ Web of Conferences (Vol. 29, p. 00016). EDP Sciences. 